\title{
Evaluation of The Relationship of The Upper Impacted Maxillary Canines with Maxillary Base
}

\section{Üst Gömülü Kanin Dişlerin Maksiller Kaide ile Illişkisinin Değerlendirilmesi}

\author{
Sanaz SADRY ${ }^{1}$ (D), Ahmet KARAMAN ${ }^{1 *}$ (D) \\ ${ }^{1}$ İstanbul Aydın Üniversitesi Diş Hekimliği Fakültesi, Ortodonti Anabilim Dalı, İstanbul, Türkiye
}

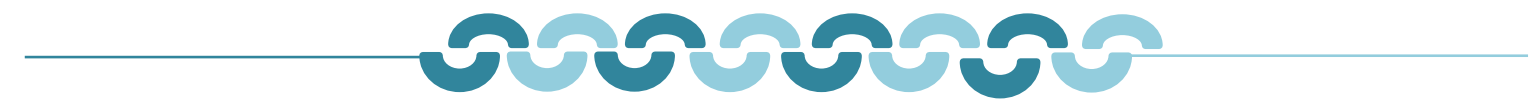

\section{A B S T R A C T}

Objective: The aim of this study was to evaluate the relationship between impacted maxillary canine teeth and maxillary base length.

Material-Method: 142 patients (67 males, 75 females; a mean age of $16.34 \pm 1.07$ years) who were admitted to the Department of Orthodontics of İstanbul Aydın University - Faculty of Dentistry for treatment were included in our study. In the retrospective study, the positions of maxillary canine teeth and their relationship with maxillary base length were examined in detail in cephalometric and panoramic radiographs. Results with $p<0.05$ were found to be statistically significant.

Results: There was no statistically significant correlation was found between gender and canine impaction. Unilaterally impacted upper canines were found to be higher between genders. Palatal plane value of the unilaterally impacted canine group was found to be statistically greater. Significant difference was found between palatal plane variable and impacted canine. No significant difference was found between age and effective midfacial length variables based on canine. Examination of the correlation between effective midfacial length and palatal plane variables revealed a strong positive correlation, which was statistically significant. There was no significant difference between age, effective midfacial length and palatal plane variables in terms of gender.

Conclusion: This study is the first to specifically address the relationship of impacted canines with the palatal plane. Therefore, the position of the canines has a major place in the evaluation of their relationship with the adjacent anatomical structures and teeth, especially during treatment planning.

Keywords: Impacted maxillary canine, cephalometry, palatal plane

Alınış / Received: 02.04.2021 Kabul / Accepted: 13.07.2021 Online Yayınlanma / Published Online: 20.12.2021 


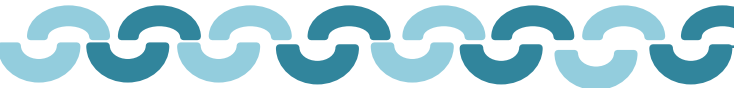

\section{Ö Z E T}

Amaç: Bu çalışmanın amacı, maksiller gömülü kanin dişlerin maksiller kaide uzunluğu ile olan ilişkilerinin değerlendirilmesidir.

Materyal-metot: Çalışmamıza İstanbul Aydın Üniversitesi Diş Hekimliği Fakültesi Ortodonti Anabilim Dalı'na tedavi için başvuran 142 hasta (67 erkek, 75 kadın; yaş ortalaması 16.34ะ1.07) üzerinde gerçekleştirilmiştir. Yapılan retrospektif çalışmada; unilateral-bilateral maksiller gömülü kanin dişlerin maksiller kaide uzunluğu ile olan ilişkileri sefalometrik ve panaromik radyografilerde incelenmiştir. $p<0.05$ için sonuçlar istatistiksel olarak anlamlı kabul edildi.

Bulgular: Cinsiyet ve gömülü kanin dişler arasında istatistiksel olarak anlamlı bir ilişki bulunmadı. Cinsiyetler arasında unilateral gömülü üst kanin dişler daha fazla bulunmuştur. Unilateral gömülü kanin grubunda palatal düzlem değeri istatistiksel olarak daha yüksek bulundu. Palatal düzlem ile gömülü kaninler arasında anlamlı fark bulundu. Maksiller kanin dişlere göre yaş ve efektif orta yüz uzunluğu değişkenleri arasında anlamlı bir fark bulunmadı. Efektif orta yüz uzunluğu ve palatal düzlem değişkenleri arasındaki ilişki incelendiğinde iki değişken arasında pozitif yönlü kuvvetli bir ilişki bulunmuştur ve istatistiksel olarak anlamlıdır. Yaş, efektif orta yüz uzunluğu ve palatal düzlem değişkenlerinin cinsiyete göre karşılaştırılmasında anlamlı bir farklılık bulunmamıştır.

Sonuç: Bu çalışma gömülü kanin dişlerin palatal düzlem ile olan ilişkisini inceleyen ilk spesifik çalışmadır. Bu nedenle kanin dişlerinin konumu, özellikle tedavi planlaması sırasında komşu anatomik yapılar ve dişlerle olan ilişkilerinin değerlendirilmesinde önemli bir yere sahiptir.

\section{Introduction}

An impacted tooth is one that fails to erupt within its normal eruption period due to lack of space, or one that fails to reach its designated location despite the availability of sufficient space and thus remains buried within the jaw bones [1,2]. Tooth eruption disorders such as impaction and ectopic eruption can occur in all permanent teeth during the mixed dentition period commonly affecting third molars and maxillary canines. The prevalence of impacted maxillary canine is seen at a rate of $1-6 \%$ in the general population [3-5]. The impaction rate of maxillary canines is twice that of mandibular canine teeth [6] Many different etiological factors such as incompatibility between the base size and teeth, congenital deficiency of lateral tooth, premature loss or prolonged retention of the deciduous canine tooth, root dilacerations, malposed tooth germ, endocrine disorders, cystic and/or neoplastic formations, and genetic causes can lead to canine impaction [7]. Various studies reported that the impaction of maxillary canines occurs 3 to 6 times more frequently in the palatal position than in the buccal position [8-10]. These articles argue that causes of impaction vary according to ethnicity. The factors involved in the impaction of maxillary canines have been the subject of numerous studies, which aimed to investigate the etiology of impacted maxillary canines. Different etiologic factors and theories have been proposed for impacted maxillary canines at different positions [11-13]. Insufficient arch length is offered as the primary etiologic factor for the impaction of canines at buccal position, while the proposed theories regarding the impaction of canine teeth at palatal position include long eruption path, persistent deciduous canine root, crowding, trauma, guidance theory and genetic theory [14-18]. Impaction of the canine tooth, which plays an important role in aesthetic, poses a problem in the development of the maxillary and mandibular arch [19,20]. Impacted teeth can remain unerupted in the jaws for years without displaying any symptoms or causing a pathological condition, and may also lead to pericoronitis, trismus, infections, temporomandibular joint problems, root resorption in 
adjacent teeth, cyst or tumor formations, decay, pain, and cheek biting [21]. Impacted canines can be treated orthodontically or surgically [11]. Impacted canines, which could not be erupted by orthodontic treatment, are surgically removed. In order to diagnose any pathology surrounding the impacted teeth, minimize complications during their extraction, and determine appropriate treatment plans, a comprehensive clinical examination and a detailed radiological examination are essential $[4,12]$. Radiological evaluation has been planned to fully evaluate the localization of the impacted upper canines in cephalometric radiograph and their relationship with the adjacent anatomical structures.

The aim of this study was to evaluate the relationship between impacted maxillary canine teeth and maxillary base length.

\section{Material and Method}

This retrospective study was approved by İstanbul Aydın University Medical Ethics Committee (2021 / 371). The study was conducted using Panoramic and Cephalometric radiographs from 142 patients who were admitted to İstanbul Aydın University Faculty of Dentistry- Department of Orthodontics Clinic for reasons such as impacted tooth extraction, implant treatment, or orthodontic assessment. The study included patients with all permanent teeth present except the maxillary wisdom teeth, with presence of unilateral or bilateral impacted canine teeth in the maxilla. Patients with craniofacial anomalies, undergoing orthodontic treatment, any trauma/orthognathic surgery, or those whose radiographs could not be clearly evaluated and any patients younger than 14 years old were excluded from the study. Cephalometric radiographs of all individuals included in the study were obtained by means of Planmeca 2011-05 Proline Pan/Ceph X-Ray unit (Planmeca, Helsinki, Finland). Patient records were digitalized using NemoCeph NX (Nemotech, Madrid, Spain) computerized cephalometric analysis system and program (Figure 1). The anatomical points and measurements used in the study were selected from Steiner and McNamara analysis. The impaction condition of the upper canines was evaluated based on age, gender, and maxillary base.

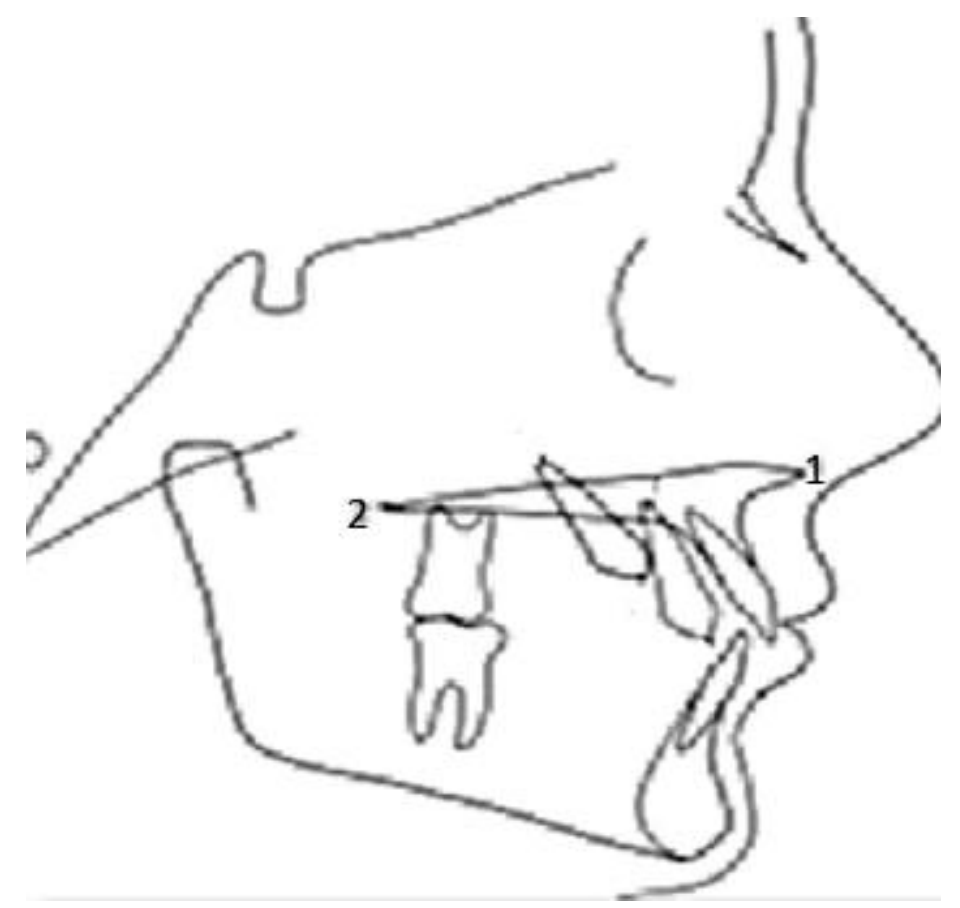

Figure 1: Cephalometric points used in lateral cephalometric analysis

1- Spina nasalis anterior (ANS): The most anterior and extreme point of the anterior nasal spine

2- Spina nasalis posterior (PNS): The posterior end point of the hard palate 


\section{Statistical Method}

SPSS 20 (SPSS Inc., Chicago, IL) program was used for data evaluation. Mean, standard deviation, minimum and maximum values were presented as descriptive statistics. Whether there was a statistically significant difference between the measurements was evaluated by Paired-t Test for values that show normal distribution, and Wilcoxon Sign Test for those that did not. Correlation tests were evaluated using Spearman or Pearson correlation coefficients. Results with $p<0.05$ were found to be statistically significant.

\section{Results}

The study included 142 patients (67 males, 75 females) with a mean age of $16.34 \pm 1.07$ years. No statistically significant correlation was found between gender and canine impaction $(p>0.05)$. The number of impacted teeth was found to be higher in females than in males. Unilaterally impacted upper canines were found to be higher between genders (Table 1). No significant difference was found between age and effective midfacial length (Co-A) variables based on canine ( $>0.05)$. Significant difference was found between palatal plane (ANS-PNS) variable and impacted canine $(p<0.05)$. Palatal plane (ANS-PNS) value of the unilaterally impacted canine group was found to be statistically greater (Table 2). There was no significant difference between age, Co-A and ANP-PNS variables in terms of gender ( $p>0.05$ ) (Table 3). Examination of the correlation between Co-A and ANS-PNS variables revealed a strong positive correlation, which was statistically significant (Table 4).

Table 1: Relationship Between Gender and Canine Variable (Chi-square Analysis)

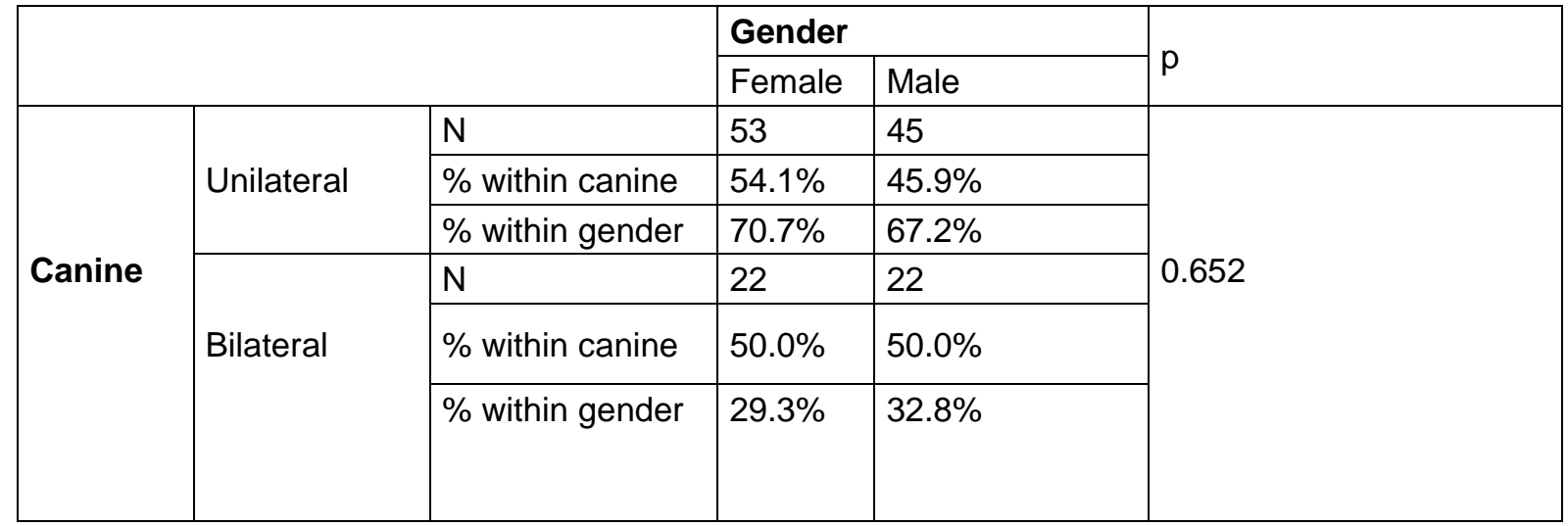

Table 2: Comparison of Age, Effective midfacial length (Co-A) and Palatal plane (ANS-PNS) according to canine status (Mann Whitney U test)

\begin{tabular}{|l|l|l|l|l|l|l|l|}
\hline & Canine & $\mathbf{N}$ & Minimum & Maximum & Mean & S.deviation & $\mathbf{p}$ \\
\hline \multirow{2}{*}{ Age } & Unilateral & 98 & 14.6 & 18.7 & 16.340 & 1.073 & \multirow{2}{*}{0.884} \\
\cline { 2 - 8 } & Bilateral & 44 & 14.5 & 17.8 & 16.241 & .8348 & \\
\hline \multirow{2}{*}{ Co-A } & Unilateral & 98 & 75 & 90 & 81.21 & 4.31 & \multirow{2}{*}{0.359} \\
\cline { 2 - 8 } & Bilateral & 44 & 73 & 88 & 79.90 & 4.12 & \\
\hline \multirow{2}{*}{ ANS-PNS } & Unilateral & 98 & 44 & 56 & 50.20 & 3.568 & \multirow{2}{*}{0.000} \\
\cline { 2 - 7 } & Bilateral & 44 & 42 & 54 & 47.02 & 3.036 & \\
\hline
\end{tabular}


Table 3: Comparison of Age, Effective midfacial length (Co-A) and Palatal plane (ANS-PNS) variables by gender (Mann Whitney U test)

\begin{tabular}{|l|l|l|l|l|l|l|l|}
\hline & & N & Minimum & Maximum & Mean & S.deviation & p \\
\hline \multirow{2}{*}{ Age } & Female & 75 & 14.5 & 18.5 & 16.24 & .9490 & \multirow{2}{*}{0.506} \\
\cline { 2 - 8 } & Male & 67 & 14.6 & 18.7 & 16.37 & 1.064 & \\
\hline \multirow{2}{*}{ Co-A } & Female & 75 & 73 & 88 & 80.51 & 3.145 & \multirow{2}{*}{0.162} \\
\cline { 2 - 7 } & Male & 67 & 75 & 90 & 81.65 & 3.377 & \\
\hline \multirow{2}{*}{ ANS- } & Female & 75 & 42 & 53 & 47.48 & 3.268 & \multirow{2}{*}{0.258} \\
\cline { 2 - 7 } & Male & 67 & 44 & 56 & 48.60 & 3.358 & \\
\hline
\end{tabular}

Table 4: The correlation between Effective midfacial length (Co-A) and Palatal plane (ANS-PNS)variables

\begin{tabular}{|c|c|c|}
\hline Spear & correlation & ANS-PNS \\
\hline & $r$ & $.839^{* *}$ \\
\hline Co-A & $p$ & .000 \\
\hline & $\mathrm{N}$ & 142 \\
\hline
\end{tabular}

\section{Discussion and Conclusion}

Maxillary canine teeth play an important role in facial appearance, dental aesthetics, arch development, and functional occlusion. Maxillary canines develop near the orbital floor of tooth germ and cover a longer path than other teeth during eruption, thus resulting in common occurrence of eruption disorders $[22,23]$. Various hypotheses have been proposed regarding the etiology of maxillary impacted canine teeth, and studies have been carried out to account for impaction etiology. In the studies, the lack of sufficient space in the dentition usually causes any tooth to be displaced and erupt into a location in the arch that is significantly different than where it should. The teeth adjacent to the canine are known to erupt before the canine itself. In the lack of sufficient space, the arch length decreases at the canine tooth's eruption location, and adjacent teeth move closer to one another on the arch preventing the buccal-to-palatine movement of the canines during eruption. Thus, the vertical eruption movement of the maxillary permanent canine is accompanied by a displacement towards the buccal. As a result, the maxillary canine tooth is forced to relocate toward the buccal due to lack of space [24]. In the literature, there are studies investigating the morphological differences in the dentition on the impacted and erupted sides [25-27]. McBride, on the other hand, argues that the reason a tooth fails to erupt into its normal position is the incompatibility between the tooth and arch sizes. If there is a lack of space on the arch, the maxillary canine tooth that is last to erupt either becomes impacted or deviates from its eruption path due to lack of space [28]. Therefore, crowding is considered to be a factor that blocks the eruption path of the permanent maxillary canine, regardless of whether the impaction occurs in the buccal or palatal. Contrary to McBride's arguments, the studies carried out by some researchers [29-32] reported that palatally displaced canines are much less likely to occur in cases with lack of space. Therefore, in this study, the impaction status of the impacted canine and its relationship with the maxilla base is discussed together. Dural et al. [32] and Yazıcı et al. [33] found that the incidence of impacted tooth was significantly higher in females than in males. In our current study, we could not find any difference in the incidence of impacted tooth between genders. This result is also consistent with the findings of Tuğsel et al. [34]. This may indicate that the canines continue their normal eruption up to a certain stage, later followed by the crown moving much closer to the midline. Although genetic origin is suggested to be the principal reason behind this deviation in the eruption path, it is also stated that it may be accompanied by factors such as lack of lateral guidance, trauma, persistence or premature loss of temporary teeth, and crowding $[17,18,31]$. Canine teeth play a key role in aesthetics, development of dental arch, and occlusion. For the 
orthodontic-surgical treatment of these teeth, their position and their relationship with the adjacent anatomical structures should be identified perfectly [35]. Palatal plane (ANS-PNS) variable showed a significant difference based on canine status. No significant difference was found for the Co-A variable based on canine status. Palatal plane (ANS-PNS) value of the unilaterally impacted canine group was found to be statistically greater. The impacted canine measured on the cephalometric section shows a significant correlation with the palatal plane.

This study is the first to specifically address the relationship of canine teeth with the palatal plane. Therefore, the position of the canines has a major place in the evaluation of their relationship with the adjacent anatomical structures and teeth, especially during treatment planning. In our study, significant difference was found between palatal plane variable and impacted canine. In light of the current literature, clinicians can have a clear idea about the status of the impacted teeth and their relationship with the adjacent anatomical structures, but devising an accurate treatment plan for impacted teeth as well as their extraction or maintenance requires a comprehensive evaluation.

\section{References}

[1] Dachi SF, Howell FV. A survey of 3, 874 routinefull-monthradiographs. II. A study of impacted teeth. Oral Surg Oral Med Oral Pathol. 1961; 14: 1165-1169.

[2] Shindel RH, Duffy SL, Maxillary transverse discrepansies and potentially impacted maxillary canines in mixeddentition patients. Angle Orthod. 2007; 77(3): 430-5.

[3] Ericson S, Kurol J. Radiographic assessment of maxillary canine eruption in children with clinical signs of eruption disturbance. Eur J Orthod. 1986; 8(3): 133-140.

[4] Hou R, Kong L, Ao J, Liu G, Zhou H, Qin R, Hu K. Investigation of impacted permanent teeth except the third molar in Chinese patients through an X-ray study. J Oral Maxillofac Surg. 2010; 68(4): 762-767.

[5] Celikoglu M, Kamak H, Oktay H. Investigation of transmigrated and impacted maxillary and mandibular canine teeth in an orthodontic patient population. J Oral Maxillofac Surg. 2010; 68(5): 1001-1006.

[6] Richardson G, Russell K A. A review of impacted permanent maxillary cuspids-diagnosis and prevention. J Can Dent Assoc. 2000;Oct;66(9):497-501.

[7] Yavuz M S, Aras M H, Büyükkurt M C, Tozoglu S. Impacted Mandibular Canines J Contemp Dent Pract 2007;8:78-85.

[8] Johnston WD. Treatment of palatally impacted canine teeth. Am J Orthod. 1969; 56(6): 589-596.

[9] Ericson S, Kurol J. Early treatment of palatally erupting maxillary canines by extraction of the primary canines. Eur J Orthod. 1988; 10(4): 283-295.

[10] Stellzig A, Basdra EK, Komposch G. The etiology of canine tooth impaction a space analysis. Fortschr Kieferorthop. 1994; 55(3): 97-103.

[11] Bishara SE. Impacted maxillary canines: a review. Am J Orthod Dentofacial Orthop. 1992; 101(2): 159-171.

[12] Jacobs SG. The impacted maxillary canine. Further observations on aetiology, radiographic localization, prevention/interception of impaction, and when to suspect impaction. Aust Dent J. 1996; 41(5): 310-316.

[13] Bedoya MM, Park JH. A review of the diagnosis and management of impacted maxillary canines. J Am Dent Assoc. 2009; 140(12): 1485-1493.

[14] Litsas G, Acar A. A review of early displaced maxillary canines: etiology, diagnosis and interceptive treatment. Open Dent J. 2011; 16(5): 39-47.

[15] Jacoby $\mathrm{H}$. The etiology of maxillary canine impactions. Am J Orthod. 1983; 84(2): 125-132.

[16] Lappin MM. Practical management of the impacted maxillary cuspid. Am J Orthod. 1951; 37(10): 769-778.

[17] Becker A, Smith $P$, Behar $R$. The incidence of anomalous maxillary lateral incisors in relation to palatallydisplaced cuspids. Angle Orthod. 1981; 51(1): 24-29.

[18] Brin I, Solomon Y, Zilberman Y. Trauma as a possible etiologic factor in maxillary canine impaction. Am J Orthod Dentofacial Orthop. 1993; 104(2): 132-137.

[19] Archer WH. Oral and Maxillofacial Surgery oVlume Fifth Edition. W.B. Saunders Company. 250-340 1975. 
[20] Warford JH Jr, Grandhi RK, Tira DE. Prediction of maxillary canine impaction using sectors and angular measurement. Am J Orthod Dentofacial Orthop. 2003; 124(6): 651-5.

[21] Santosh P. Impacted Mandibular Third Molars: Review of Literature and a Proposal of a Combined Clinical and Radiological Classification. Ann Med Health Sci Res.2015;5(4):229-34.

[22] Broadbent BH. Ontogenic development of occlusion. Angle Orthod. 1941; 11: 223-241.

[23] Coulter J, Richardson A. Normal eruption of the maxillary canine quantified in three dimensions. Eur $\mathrm{J}$ Orthod. 1997; 19(2): 171-183.

[24] Dalkılıç A. Evaluation of periodontal status of ectopic canines after orthodontic treatment. Marmara University Institute of Health Sciences, Doctorate Thesis, Istanbul, (Ass. Prof. Ahu Acar), 2008; 15-18.

[25] Alqerban A, Jacobs R, Fieuws S, Willems G. Radiographic predictors for maxillary canine impaction. Am J Orthod Dentofacial Orthop. 2015; 147(3):345-354.

[26] Kim Y, Hyun HK, Jang KT. Morphological relationship analysis of impacted maxillary canines and the adjacent teeth on 3-dimensional reconstructed CT images. Angle Orthod. 2017; 87(4): 590-597.

[27] Tadinada A, Mahdian M, Vishwanath M, Allareddy V, Upadhyay M, Yadav S. Evaluation of alveolar bone dimensions in unilateral palatally impacted canine: a cone-beam computed tomographic analyses. Eur J Orthod. 2015 ; 37(6): 596-602.

[28] McBride LJ. Traction a surgical/orthodontic procedure. Am J Orthod. 1979; 76(3): 287-299.

[29] Fischer TJ. Orthodontic treatment acceleration with corticotomy-assisted exposure of palatally impacted canines. Angle Orthod. 2007; 77(3): 417-20.

[30] Becker A. Etiology of maxillary canine impactions. Am J Orthod. 1984; 86(5):437-438.

[31] Brin I, Becker A, Shalhav M. Position of the maxillary permanent canine in relation to anomalous or missing lateral incisors: a population study. Eur J Orthod. 1986; 8(1): 12-16.

[32] Dural S, Avcı N, Karabıyıkoğlu T. Gömük dişlerin görülme sıklığı, çenelere göre dağılımları ve gömülü kalma nedenleri. Sağ Bil Arş Derg 1996;7:127-33.

[33] Yazıcı S, Kökden A, Tank A. Gömülü Dişler Üzerine Retrospektif Bir Çalışma. Cumhuriyet Üniversitesi Diş Hek Fak Derg 2002;5(2):46-51.

[34] Tuğsel Z, Kandemir S, Küçüker F. Üniversite öğrencilerinde üçüncü molarların gömüklülük durumlarının değerlen dirilmesi. Cumhuriyet Üniversitesi Diş Hek Fak Derg 2001;4:102-5.

[35] Tantanapornkul W, Okouchi K, Fujiwara Y, et al. A comparative study of cone-beam computed tomography and conventional panoramic radiography in assessing the topographic relationship between the mandibular canal and impacted third molars. Oral Surg Oral Med Oral Pathol Oral Radiol Endod.2007;103(2):253-9. 